\title{
The Influence of Marital Satisfaction on Child's Peer-Play Behavior and Problem Behavior: The Mediated Effects of Father's and Mother's Parenting Behavior
}

\author{
Go Woon Suh \\ Department of Psychology, Yonsei University, Seoul, Korea \\ 부모의 결혼만족도가 아동의 또래 놀이 행동과 문제행동에 미치는 영향: \\ 아버지와 어머니 양육행동의 매개효과 \\ 서고운 \\ 연세대학교 심리학과
}

\begin{abstract}
Objective: This study examined the mediational effects of father's and mother's parenting behavior in the relation between marital satisfaction and child peer-play behavior and in the relation between marital satisfaction and child problem behavior.

Methods: The data in this study came from the Panel Study on Korean Children, using Wave 3 data $(N=1,802)$ for marital satisfaction, Wave 5 data $(N=1,703)$ for parenting behavior, and Wave 7 data $(N=1,620)$ for child peer-play behavior and problem behavior.

Results: First, father's warm parenting behavior mediated the relation between marital satisfaction and child peer-play behavior. Second, father's and mother's warm parenting behavior mediated the relation between marital satisfaction and child problem behavior.

Conclusion: The role of fathers was highlighted regarding the effects of marital satisfaction on child-developmental outcomes. Child peer-play behavior, especially, was predicted only by father's warm parenting behavior but not by mother's warm parenting behavior.
\end{abstract}

Keywords: PSKC, marital satisfaction, father, parenting, peer-play

\begin{abstract}
서론
부부관계가 아동의 발달에 영향을 미칠 때, 부모의 양육행동 이 그 영향력을 매개하는지는 수많은 연구들에 의해 검증되 어져 왔다(e.g., Gerard, Krishnakumar, \& Buehler, 2006; Sears, Repetti, Reynolds, Robles, \& Krull, 2016). 하지만, 대부분의 연 구들이 횡단적인 데이터를 이용하였고, 부부관계의 여러 측면 중 주로 부부갈등을 연구 변인으로 사용하였으며, 부모 중 주

Corresponding Author: Go Woon Suh, Department of Psychology, Yonsei University, 50, Yonsei-ro, Seodaemun-gu, Seoul, Korea

E-mail: gowoonsuh2@gmail.com
\end{abstract}

로 어머니만을 연구 대상으로 포함시킴으로써, 가족 구성원들 간의 다양하고 역동적인 종단적 영향력에 대한 통합적 이해를 제공하지는 못하였다. 본 연구는, 부부관계의 여러 측면 중 결 혼만족도에 초점을 맞추었으며, 아버지와 어머니의 독립적인 영향력을 모두 살펴보았다. 또한 종단적으로 모아진 한국아동 패널연구 데이터를 이용함으로써, 부부의 결혼만족도에서 시 작하여 부모의 양육행동, 그리고 아동의 발달로 이어지는 종 단적인 매개경로에 대한 보다 통합적이고 명확한 이해를 제공

(C)The Korean Association of Child Studies

This is an Open Access article distributed under the terms of the Creative Commons Attribution Non-Commercial License (http:// creativecommons.org/licenses/by-nc/4.0) which permits unrestricted noncommercial use, distribution, and reproduction in any medium, provided the original work is properly cited. 
하고자 한다.

부부관계는 아동 발달에 직접적 영향을 줄 뿐 아니라, 부모 의 양육행동 또는 부모-아동 관계를 거쳐 아동 발달에 간접적 으로 영향을 준다. 부부관계가 부모의 양육행동 또는 부모-아 동 관계에 어떻게 영향을 주는지를 설명하는 이론적 틀로는 크게 3가지가 있다(Krishnakumar \& Buehler, 2000). 첫째, 전이 가설(spillover hypothesis)은 부부관계에서 느끼는 감정들이 부 모와 아동과의 관계에 전이된다고 설명한다. 둘째, 보상가설 (compensatory hypothesis)은 부부갈등으로부터 야기된 좌절 혹 은 불만족과 같은 감정들이 부모로 하여금 아동과의 관계에 더욱 집중하게 만들면서 상쇄되어진다고 설명한다. 마지막으 로 분리가설(compartmentalization hypothesis)은 부모는 부부관 계와 부모로써의 역할을 분리할 수 있어서, 부부관계와 부모 의 양육행동 또는 부모와 아동 사이의 관계가 관련을 보이지 않을 것이라고 설명한다. 여러 논문들을 대상으로 메타 분석 을 실시한 Krishnakumar와 Buehler (2000)의 논문은 보상가설 과 분리가설보다는 전이가설이 부부관계와 부모의 양육행동 또는 부모-아동 관계를 보다 더 잘 설명한다고 보고하였다. 본 연구는 한국 아동 가족을 대상으로 부부관계와 부모의 양육행 동 간의 관계를 살펴봄으로써, 한국 문화권에서도 전이가설이 두 변인 간의 관계를 가장 잘 설명하는지 탐색하였다.

특히, Cummings, Merrilees와 George (2010)는 아버지의 양 육행동 또는 아버지-아동 관계가 어머니의 양육행동 또는 어머니와-아동 관계보다 부부관계에 더 큰 영향을 받을 것 이라는 아버지 양육행동 취약성 가설(fathering vulnerability hypothesis)을 제안하였다. 왜 아버지의 양육행동이 어머니의 양육행동보다 부부관계에 더 많은 양향을 받는지에 대한 설 명으로는, 성 역할 이론이 대표적이다. 성 역할 이론은 어머 니는 아내와 어머니로써의 역할을 잘 분리하는 반면, 아버지 는 남편과 아버지로써의 역할을 잘 분리하지 못하기 때문에, 남편으로써 겪게 되는 스트레스를 아동과의 관계에 더 잘 전 이시킨다고 설명한다(Cummings, Merrilees, \& Ward-George, 2010). 또 다른 설명으로는, 어머니의 문지기 행동(maternal gatekeeping behaviors) 때문이라는 주장도 있다. 이 가설은 부 부관계가 나쁘면 어머니가 아버지와 아동이 상호작용하는 것 을 제한하고 막기 때문에, 부부관계가 아버지와 아동의 관계 에 영향을 끼친다고 설명한다(Stevenson et al., 2014). 실제로, Stevenson et al. (2014)의 논문은 어머니가 느끼는 결혼 문제 들이 어머니의 문지기 행동을 증가시키고, 증가된 문지기 행 동들이 아버지와 아동의 상호작용을 감소시킨다는 연구결과 를 보여주었다. 이 외에도 많은 경험 연구들이 아버지의 양육
행동 혹은 아버지-아동 관계가 어머니의 양육행동 혹은 어 머니-아동 관계보다 부부관계에 더 많은 영향을 받는다는 아버지 양육행동 취약성 가설을 검증하였으나(Sturge-Apple, Davies, \& Cummings, 2006; Suh et al., 2016), 한국 아동 가족을 대상으로 하는 연구는 매우 부족한 실정이다. 또한 대부분의 논문들이 부부관계의 영향력을 검증하는데 있어 표면적으로 쉽게 나타나는 부부갈등(parent conflict)에 큰 초점을 맞추어왔 다. 하지만 부부갈등 이외에도 전반적인 부부관계의 질을 표 상하는 결혼만족도도 무시되어서는 안 되는 부부관계의 중요 한 요인이다. 따라서 본 논문은 어머니와 아버지의 영향력을 분리하여 그들의 결혼만족도가 양육행동에 어떠한 영향을 끼 치는지 살펴보았다.

한편, 부모의 양육행동은 다양한 방식으로 세분화되어 연 구되어져 왔다. 그 중 대표적인 접근 방식으로 양육행동의 유 형화(typology)와 차원화(dimension)가 있다(Hoeve et al., 2009). Baumrind (1971)에 의해 소개된 양육행동의 유형화는, 권위주 의적(authoritarian), 허용적(permissive), 권위있는(authoritative) 양육방식으로 나뉘어지며, 많은 연구자들에 의해 검증되어졌 으나, 아시아 부모들의 양육행동은 잘 설명하지 못한다는 지 적을 받았다(Cho, Lee, Lee, \& Kwon, 1999). 양육행동의 차원 화는 크게 온정(support/warmth)과 통제(control)로 나뉘어지 며, 통제는 다시 정신적 통제(psychological control)와 행동적 통제(behavioral control)로 나뉘어진다(Hoeve et al., 2009). 온 정 차원은 아동을 편안하고 인정받는 느낌이 들게 해주는 양 육행동으로 대부분 아동의 긍정적인 발달과 관련되어져 있으 며, 정신적 통제는 아동에 대한 사랑을 철회하는 방식 등을 이 용하여 아동의 정신적 발달을 침해하는 양육행동으로 알려 져 있다(Hoeve et al., 2009). 행동적인 통제 차원은 규칙을 세 우거나 모니터링을 통해 아동의 행동을 규제하려는 양육행동 으로(Hoeve et al., 2009), 아동의 학업 성취에 긍정적인 영향을 주었고(Pinquart, 2016), 감소된 외현화 문제행동(externalizing problems)과 관련이 있었다(Pinquart, 2017). 본 연구는 아동 발 달에 긍정적인 영향을 준다고 알려져 온 온정적 양육과 행동 적 통제 양육의 역할에 주목하였는데, 학령기 이전의 아동들 에게도 이러한 양육행동이 아동 발달에 긍정적인 영향을 주는 지 검증하였다.

부모의 양육행동은 아동의 우울(Mcleod, Weisz, \& Wood, 2007), ADHD (Healey, Flory, Miller, \& Halperin, 2011; Shin, Chung, \& Choi, 2010)를 포함하는 정신적 문제, 아동의 학업 성취도(Masud, Thurasamy, \& Ahmad, 2015), 문제 행동(Lee, 2016; Pinquart, 2017) 등 다양한 아동의 발달 영역에 영향을 
끼친다고 연구되어져 왔다. 양육행동이 아동의 발달에 영향 을 미치는 메커니즘은 다양한 이론들에 의해 설명되어지는데 (Kawabata, Alink, Tseng, van Ijzendoorn, \& Crick, 2011), 부모의 양육행동이 모델링, 강화, 처벌 등을 제공하여 아동의 발달에 영향을 미친다는 사회 학습 이론과 부모와의 상호작용으로 형 성되는 내적 작동 모델이 아동의 발달에 영향을 미친다는 애 착 이론이 대표적이라고 할 수 있다.

이렇게 많은 연구들이 부모의 양육행동과 아동 발달의 밀 접한 관련성에 대한 이론적, 경험적 증거들을 제공하고 있음 에도 불구하고, 아버지의 양육행동이 아동의 발달에 미치는 영향에 대한 이해는 매우 제한적이다. 하지만, 많은 연구자들 이 아동 발달에 대한 아버지와 어머니의 독립적인 영향력을 살펴보아야 한다는 것을 강조하였다. 특히, 아동의 또래 관계 와 내재화, 외현화 문제 행동은 아버지의 영향력이 강조되어 지는 아동 발달의 영역들이다. Bowlby (1982)는 아동에게 있 어 아버지가 어머니보다 더 신뢰받는 놀이 상대라고 언급하였 으며, Leidy, Schofield와 Parke (2013)는 아동의 또래 관계를 포 함하는 사회성 발달은 아버지의 영향력과 밀접한 관련이 있 다고 제안하였다. 이러한 관련성은 아버지의 부재가 아동의 또래 관계 문제에 영향을 준다는 1950 년대의 초기 연구들에 서 제기되기 시작하여(Lynn \& Sawrey, 1959; Stolz, 1954), 아버 지의 양육행동이 아동의 친사회적 행동 및 또래 관계에 영향
을 준다는 최근의 연구들에서까지 논의되어지고 있다(Jang \& Lee, 2008; Yamagata et al., 2013). 뿐만 아니라, 아동의 내재화, 외현화 문제행동에 대한 아버지의 영향력도 많은 관심을 받아 왔다. 부모의 양육행동과 아동의 불안 간의 관계에 관한 논문 (28개의 어머니 양육에 관한 논문과 12 개의 아버지 양육에 관 한 논문)들로 메타분석을 실시한 Möller Nikolić, Majdandžić과 Bögels (2016)의 논문은 어머니의 도전적 양육행동(challenging parenting)은 아동의 불안과 관련되어있지 않으나, 아버지의 도전적 양육행동은 아동의 불안을 적게 해준다고 밝혔다. 도 전적 양육 행동은, 신체놀이(rough and tumple play), 아이들과 경쟁하기 등과 같은 아동을 신체적으로, 그리고 사회-정서적 으로 도전할 수 있게 하는 양육 방식을 의미한다. 또한 부모의 양육행동과 아동의 공격성 간의 관계에 관한 48 개의 논문들 로 메타분석을 실시한 Kawabata et al. (2011)의 논문은 어머니 의 사랑의 철회, 죄책감 불러일으키기와 같은 정신적 통제 양 육(psychologically controlling parenting)은 아동의 관계 공격성 과 관련성을 보이지 않았으나, 아버지의 정신적 통제 양육은 아동의 관계 공격성과 관련성을 보였다고 보고하였다.

따라서 본 연구는 부부의 결혼만족도에서 시작하여 부모 의 양육행동, 그리고 아동의 또래 놀이 행동과 문제행동으로 이어지는 경로의 탐색에서, 아버지와 어머니의 역할을 분리 하여, 그들의 독립적인 역할을 검증하였다. 결혼만족도는 한

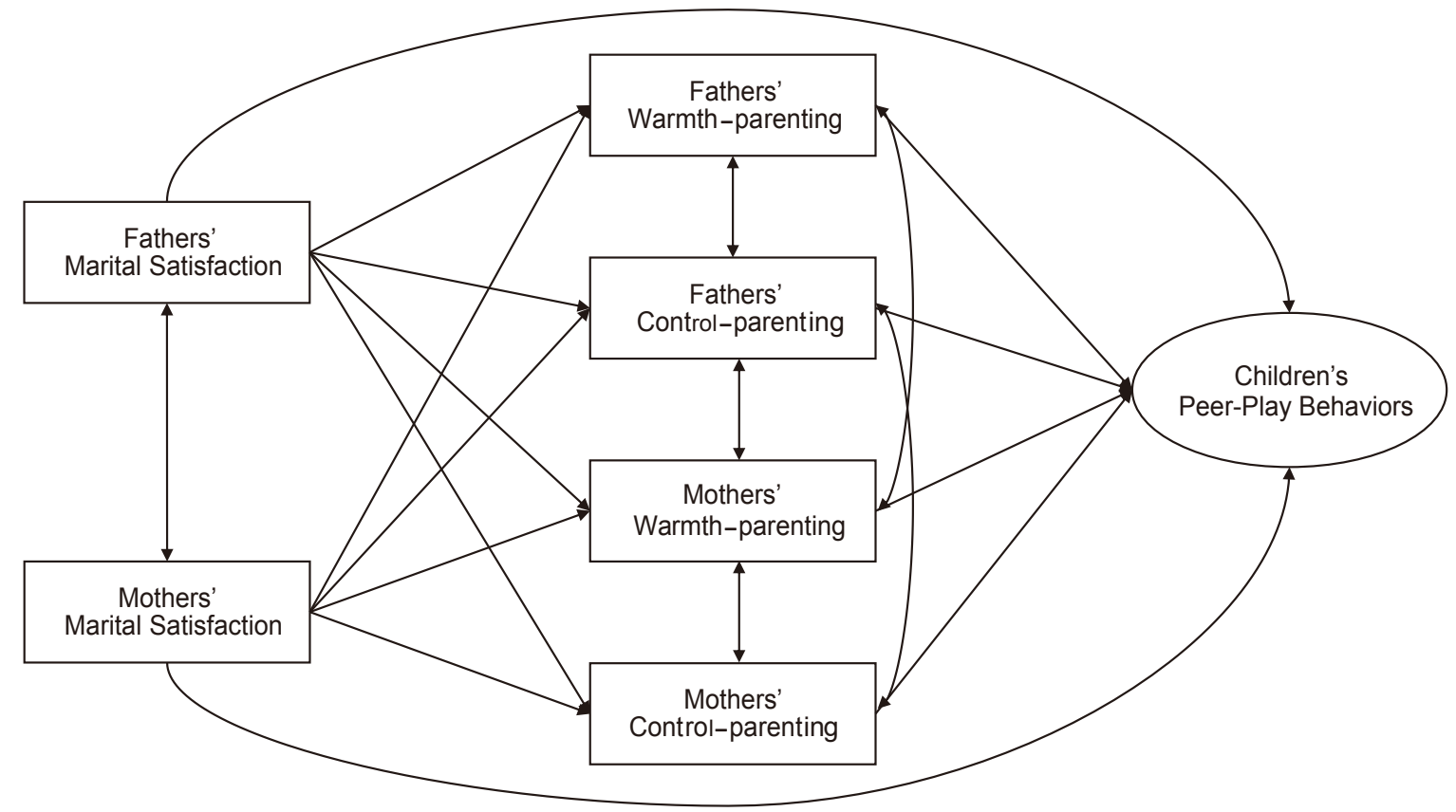

Figure 1. Research model for child peer-play behavior. 


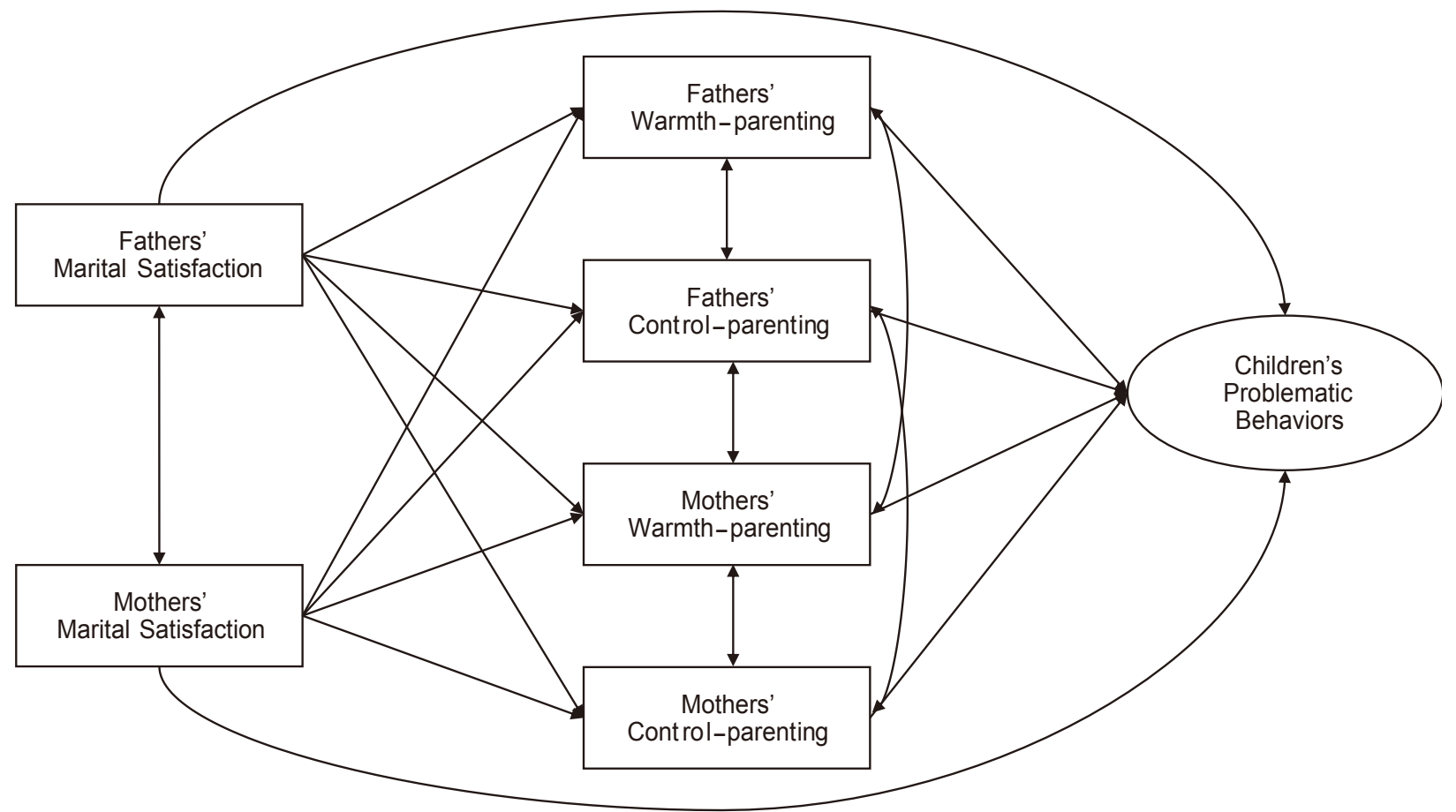

Figure 2. Research model for child problem behavior.

국아동페널연구 데이터의 3 차년도(아동 2 세) 데이터를 사용 하였으며, 부모의 양육행동은 5 차년도(아동 4 세), 아동의 또 래 놀이 행동과 문제행동은 7차년도(아동 6세) 데이터를 이용 함으로써, 종단적인 인과관계를 보다 명확히 검증하고자 하였 다. 특히, 아동이 2 세 때는 부부가 결혼 한지 얼마 되지 않는 결 혼 초기인 동시에 양육 스트레스로 인하여 부부관계가 많이 흔들릴 수 있는 시기이므로 부모의 결혼만족도의 영향력을 확 인할 수 있는 적당한 시기라 생각되며, 아동이 4세 때는 부모 의 양육행동이 어느 정도 안정화 되어가는 시기로 부모의 양 육행동 효과를 볼 수 있는 절절한 시기라 생각된다. 또한 6세 는 또래와의 사회적 관계 형성이 중요해지는 시기인 동시에 사회적 활동 범위가 넓어지면서 다양한 문제행동을 보일 수 있는 시기이기 때문에, 아동의 또래 관계와 문제행동에 대한 부모의 영향력을 검증하기에 적합한 시기라고 판단되었다. 또 한 부모의 양육행동도 온정 차원과 통제 차원을 분리하여, 각 차원의 독립적 영향력을 살펴보았다. 최종 종속변인인 아동의 또래 놀이 행동과 문제행동은 개별적인 모델에서 검증되어졌 는데, 연구 가설들을 바탕으로 구현한 연구모델은 Figure 1(또 래 놀이 행동 모델)과 Figure 2(문제 행동 모델)와 같다. 종속변 인은 하위요인들을 이용한 잠재변인을 사용하였다.

각 연구모델 별 구체적인 연구문제는 다음과 같다.

\section{연구문제 1}

〈아동의 또래 놀이 행동 모델〉

부모의 양육행동(아버지의 온정적, 통제적 양육행동과 어머 니의 온정적, 통제적 양육행동)은 부부의 결혼만족도(아버지 가 지각한 결혼만족도와 어머니가 지각한 결혼만족도)와 아 동의 놀이 행동을 매개하는가?

\section{연구문제 2}

〈아동의 문제행동 모델〉

부모의 양육행동(아버지의 온정적, 통제적 양육행동과 어머 니의 온정적, 통제적 양육행동)은 부부의 결혼만족도(아버지 가 지각한 결혼만족도와 어머니가 지각한 결혼만족도)와 아 동의 문제행동을 매개하는가?

\section{연구방법}

\section{연구대상}

본 연구는 육아정책연구소 한국아동패널연구(PSKC) 데이터 를 이용하였다(Korea Institute of Childcare and Education, 2011, 
2013, 2015). 한국아동패널연구 데이터는 2008년 출생한 신생 아 가구를 모집단으로 하여, 층화다단계 추출법을 적용하여 2,150 가구의 전체 표본을 구축하였으며, 현재 7차년도(2014 년) 데이터까지 이용가능하다. 본 연구는 독립변인, 매개변인, 종속변인들 간의 종단적인 영향력을 살펴보기 위하여 변인들 간에 다른 차수년도( $3,5,7$ 차년도)의 데이터를 이용하였다.

전체 표본 2,150 가구 중, 3 차년도에는 1,802 가구가 조사되 어졌다. 3 차년도 아동의 만 월령은 26 개월이었고, 성별은 남 아가 $50.9 \%$, 여아가 $49.1 \%$ 로 균등하였다. 어머니의 평균 연령 은 33세였으며, 아버지의 평균 연령은 35세였다. 어머니의 학 력은 고졸이하가 $29.9 \%$, 전문대졸이 $25 \%$, 대졸이 $39.9 \%$, 대 학원졸 이상이 $5.3 \%$ 였다. 아버지의 학력은 고졸이하가 $26 \%$, 전문대졸이 $18.5 \%$, 대졸이 $45.7 \%$, 대학원졸 이상이 $9.9 \%$ 였 다. 5 차년도에는 1,703 가구(아동연령평균: 만 4세 3 개월) 가 조사되어졌으며, 7 차년도에는 1,620가구(아동연령평균: 만 6 세 2개월) 가 조사되어졌다.

\section{연구도구}

본 연구의 독립변인인 결혼만족도 변인은 3차년도 데이터를 이용하였고, 매개변인인 부모의 양육행동 변인은 5 차년도의 데이터를 이용하였으며, 종속변인인 아동의 또래 놀이 행동과 문제행동 변인은 7차년도의 데이터를 이용하였다. 각 변인을 측정한 연구도구들을 구체적으로 살펴보면 다음과 같다.

\section{결혼만족도}

아버지와 어머니가 지각한 결혼만족도는 KMSS (Kansas Marital Satisfaction Scale; Schumm, Nicols, Schectman, \& Grigsby, 1983)를 Chung (2004)이 우리나라 문화에 맞게 수정 한 RKMSS (Revised-Kansas Marital Satisfaction Scale)로 측정되 어졌다. 아버지와 어머니가 총 4 문항으로 구성되어져 있는 RKMSS에 각각 응답하였다. 구체적인 문항의 예는 "귀하는 결혼생활에 얼마나 만족하십니까?” 또는 "귀하는 남편/아내와 의 관계에 대해 얼마나 만족하십니까?” 등과 같다. 각 문항은 Likert식 5점 척도로 구성되었으며, 점수가 높을수록 부모가 지각하는 결혼만족도의 정도가 높음을 의미한다. 3 차년도 아 버지가 지각한 결혼만족도 신뢰도(Cronbach's $\alpha$ )는 .92, 어머 니가 지각한 결혼만족도 신뢰도(Cronbach's $\alpha$ )는 .92였다. 본 연구에서는 총 4 문항의 평균점수를 아버지가 지각한 결혼만 족도, 어머니가 지각한 결혼만족도 점수로 이용하였다.

\section{양육행동}

아버지와 어머니의 양육행동은 Cho et al. (1999)의 문항을 참 고하여 한국아동패널 연구진이 자체 제작한 도구로 측정되어 졌다. 아버지와 어머니가 총 12 문항으로 구성되어져 있는 본 척도에 각각 응답하였다. 본 척도는 온정적 양육(6개 문항)과 통제적 양육(6개 문항)의 2가지 하위영역으로 나뉘어진다. 온 정적 양육의 구체적인 문항의 예는 "아이와 친밀한 시간을 갖 는다." 또는 "아이의 의견을 존중하고 표현할 수 있게 한다." 등과 같다. 통제적 양육의 구체적인 문항의 예는 "나는 지켜 야 할 규칙, 규율을 세우고 아이가 지키도록 한다.” 또는 "나는 가정교육을 위해 아이의 행동을 제한한다.” 등과 같다. 각 문 항은 Likert식 5점 척도로 구성되었으며, 점수가 높을수록 온 정적 양육과 통제적 양육의 정도가 높음을 의미한다. 5 차년도 아버지의 온정적 양육 신뢰도(Cronbach's $\alpha$ )는 .86, 통제적 양 육 신뢰도(Cronbach's $\alpha$ )는 .82, 어머니의 온정적 양육 신뢰도 (Cronbach's $\alpha$ )는 .86, 통제적 양육 신뢰도(Cronbach's $\alpha$ )는 .76 였다. 본 연구에서는 각 하위영역의 평균점수를 아버지의 온 정적 양육, 아버지의 통제적 양육, 어머니의 온정적 양육, 어머 니의 통제적 양육 점수로 이용하였다.

\section{아동의 또래 놀이 행동}

아동의 또래 놀이 행동은 Fantuzzo, Coolahan, Mendez, McDermott와 Sutton-Smith (1998)를 Choi와 Shin (2008)이 타당 화한 내용을 참고하여, 한국아동패널 연구진이 검토, 수정하 여 확정한 도구로 측정되어졌다. 아동의 어머니가 총 30 개의 문항으로 이루어진 본 척도에 응답하였다. 본 척도는 친사회 적인 특성과 놀이를 순조롭게 이어가는 특성 등을 측정하는 놀이 상호작용(9개 문항), 공격적이고 부정적인 정서 표현 등 을 측정하는 놀이 방해(13개 문항), 위축되거나 타인에게 무시 또는 거부당하는 특징 등을 측정하는 놀이 단절(8개 문항)의 3 가지 하위영역으로 나뉘어진다. 놀이 상호작용의 구체적인 문항의 예는 “친구를 돕는다." 또는 “친구 사이의 갈등이 해결 되도록 돕는다.” 등과 같다. 놀이 방해의 구체적인 문항의 예 는 “차례를 지키지 않는다." 또는 "친구들이 놀이에 대해 제안 하는 것을 받아들이지 않는다.” 등과 같다. 놀이 단절의 구체 적인 문항의 예는 "위축되어 있다." 또는 "목적 없이 돌아다닌 다.” 등과 같다. 각 문항은 Likert식의 4점 척도로 구성되어져 있다. 놀이 상호작용의 점수가 높을수록 긍정적인 놀이의 상 호작용이 이루어지고 있음을 의미하며, 놀이 방해와 놀이 단 
절의 점수가 높을수록 부정적인 놀이 행동을 보인다는 것을 의미한다. 7차년도 놀이 상호작용의 신뢰도(Cronbach's $\alpha$ )는 .81 , 놀이 방해 신뢰도(Cronbach's $\alpha$ )는 .86, 놀이 단절 신뢰도 (Cronbach's $\alpha$ )는 .89였다. 본 연구에서는 각 하위영역의 평균 점수를 놀이상호작용, 놀이 방해, 놀이 단절의 점수로 이용하 였다.

\section{아동의 문제 행동}

아동의 문제 행동은 Achenbach와 Rescorla (2000)가 개발한 Child Behavior Checklist [CBCL] 1.5-5세용 척도를 Oh와 Kim (2009)이 한국판으로 번역한 도구로 측정되어졌다. 아동의 어 머니가 총 100 개의 문항으로 이루어진 본 척도에 응답하였다. 본 척도는 낮선 상황 및 변화에 대한 걱정, 저항 등을 측정하 는 정서적 반응성(9개 문항), 불안과 슬픔 등 부정적 감정과 관 련된 특성을 측정하는 불안/우울(8개 문항), 분명한 의학적 원 인 없이 나타나는 예민함과 관련된 특성을 측정하는 신체 증 상(11개 문항), 위축과 무관심한 특성을 측정하는 위축(8개 문 항), 수면문제(7개 문항), 과잉행동 및 둔한 운동신경을 측정 하는 주의집중문제(5개 문항), 반항적이고 분노발장 등을 측 정하는 공격행동(19개 문항), 그 외 새로운 것에 대해 겁을 내 는 것이나 이유 없이 잘 다침과 같은 다른 요인들과는 겹치지 않는 문제 행동을 측정하는 기타문제(33개 문항)의 8 가지 하 위영역으로 나뉘어진다. 각 문항은 Likert식의 3점 척도로 구 성되어졌으며, 점수가 높을수록 각 영역과 관련된 문제 행동 의 정도가 높다는 것을 의미한다. 7 차년도 정서적 반응성의 신 뢰도(Cronbach's $\alpha$ )는 .74, 불안/우울의 신뢰도(Cronbach's $\alpha$ ) 는 .72, 신체증상의 신뢰도(Cronbach's $\alpha$ )는 .57, 위축의 신뢰도 (Cronbach's $\alpha$ )는 .65, 수면문제의 신뢰도(Cronbach's $\alpha$ )는 .55, 주의집중문제의 신뢰도(Cronbach's $\alpha$ )는 .62, 공격행동의 신 뢰도(Cronbach's $\alpha$ )는 .87 , 기타문제의 신뢰도(Cronbach's $\alpha$ )는 .81 였다. 본 연구에서는 각 하위영역의 총점을 각 하위영역의 점수로 이용하였다.

본 척도는 임상적 혹은 연구적 목적에 따라 다양한 하위 척 도들로 세분화하여 사용되어지기도 하는데, 예를 들어 임상학 적 문제 행동에 초점을 맞출 때에는 DSM방식의 척도로 세분 화하기도 하고, 혹은 위의 하위 영역들을 조합하여 내재화 문 제 행동(정서적 반응성, 불안/우울, 신체증상, 위축), 외현화 문 제 행동(주의집중문제, 공격행동)으로 세분화하기도 한다. 이 러한 세분화된 방법 외에도 위에 제시된 모든 하위영역을 포 함하는 총 문제 행동 척도를 사용하기도 한다. 본 연구는 모든
문항을 사용하는 총 문제 행동 척도를 사용하였는데, 내재화 문제 행동과 외현화 문제 행동으로 구분하여 살펴보면, 내재 화 혹은 외현화 문제 행동으로 세분화 되어질 수는 없지만, 아 동들에게 흔히 나타나는 문제 행동인 수면문제(7문항)와 기타 문제(33문항) 영역을 포함시킬 수 없기 때문이었다. 또한 내재 화, 외현화 문제 행동들의 증상들은 상관이 높고, 공존의 가능 성이 높기 때문에 구분하여 검증하기 보다는 총 문제 행동으 로 살펴보는 것이 더 적절하다고 판단하였다. McConaughy와 Skiba (1993)는 CBCL 하위 영역 간의 상관이 높다는 문제를 지적하였으며, Willner, Gatzke-Kopp와 Bray (2016)는 유치원생 과 초기 아동기의 많은 아이들 역시 내재화와 외현화 문제 행 동을 공존(comorbidity)하여 지니고 있다고 밝혔다.

\section{자료분석}

부모의 양육행동이 부부의 결혼만족도와 아동의 발달을 매개 하는지를 검증하는 두 개의 모델이 검증되었다. 구체적으로 우선, 아동의 또래 놀이 행동을 종속변인으로 하는 모델이 검 증되었다. 두 번째로, 아동의 문제 행동을 종속변인으로 하는 모델이 검증되었다. 종단적인 매개효과를 검증하기 위해, 부 부의 결혼만족도는 3 차년도 데이터를 이용하였고, 부모의 양 육행동은 5 차년도 데이터를 이용하였으며, 아동의 또래 놀이 행동과 문제 행동은 7차년도 데이터를 이용하였다. 아동의 또 래 놀이 행동과 문제 행동은 하위요인들을 이용한 잠재변인을 사용하였다.

모델은 Mplus 7.31 (Muthén \& Muthén, 1998-2002)로 검 증되어졌다. 결측치 문제를 위해서 Maximum likelihood (ML) 방법이 사용되었다(Baraldi \& Enders, 2010). ML은 Multiple Imputations (MI)과 더불어, 결측치를 다루는 가장 좋은 현대 적 방법으로 추천된다(Baraldi \& Enders, 2010). ML은 원자료 (raw data)를 가장 잘 설명하는 모델의 계수들을 산출하기 위 해, 이용가능한 모든 데이터를 이용한다(Baraldi \& Enders, 2010). 아동의 문제 행동 모델은 아동의 문제 행동의 두 하위 요인(신체증상의 kurtosis $=4.33$, 위축의 kurtosis $=4.33$ )이 다 소 비정규적인 분포(non-normality)를 보였기 때문에, 비정규 성을 보이는 변인에 영향을 잘 받지 않는 Maximum Likelihood Robust (MLR) 방법이 사용되었다. 매개경로의 유의미성은 bootstrapping에 의해 산출된 신뢰구간을 통하여 검증되어졌으 며, 매개경로 계수의 신뢰구간이 0 을 포함하지 않으면 유의미 하다고 판단된다(MacKinnon, 2008). 평균 및 상관 등의 기초통 계들은 SPSS 23.0 (IBM Co., Armonk, NY)으로 산출되어졌다. 


\section{연구결과}

\section{변인들의 평균과 변인들 간의 상관}

Table 1 은 아동의 또래 놀이 행동 모델 변인들의 평균과 변인 들 간의 상관을 보여준다. 우선, 각 차년도 내에서의 변인 간 상관을 살펴보면 다음과 같다. 첫째, 아동이 2 세일 때 측정한 부모의 결혼만족도 변인들 간 상관을 살펴보면, 아버지가 지 각한 결혼만족도가 높을수록, 어머니가 지각한 결혼만족도가 높았다. 둘째, 아동이 4세일 때 측정한 부모의 양육행동 변인 들 간 상관을 살펴보면, 아버지의 온정적 양육이 높을수록, 어 머니의 온정적 양육이 높았으며, 아버지의 통제적 양육이 높 을수록, 어머니의 통제적 양육도 높았다. 아버지와 어머니의 온정적 양육과 통제적 양육도 정적 상관을 보였다. 본 연구에 서 측정한 통제적 양육은 규칙을 세우거나 모니터링을 통해 아동의 행동을 규제하는 행동적 통제 측면이라는 것을 기억할 필요가 있다. 특히, 양육행동을 측정했던 4세 시기는, 규칙과 행동 통제를 배워야하는 시기로 부모의 적절한 통제적 양육이 필요한 시기라고 보여진다. 따라서 부모의 온정적 양육행동과 통제적 양육행동 간의 정적 상관관계 결과는 타당하다고 보여 진다. 셋째, 아동이 6세일 때 측정한 놀이 행동 변인들 간 상관 을 살펴보면, 놀이 상호작용이 높을수록, 놀이 방해와 놀이 단 절은 낮은 점수를 보였고, 놀이 방해가 높을수록, 놀이 단절도
높았다.

다음으로, 부모가 지각한 결혼만족도와 부모의 양육행동 간의 상관을 살펴보면, 아동 2 세 때 아버지가 지각한 결혼만족 도와 어머니가 지각한 결혼만족도가 높을수록, 아동 4 세 때 아 버지의 온정적 양육과 어머니의 온정적 양육이 높았다. 하지 만 아동 2 세 때 아버지와 어머니가 지각한 결혼만족도는 아동 4 세 때의 아버지와 어머니의 통제적 양육과는 유의미한 상관 을 보이지 않았다.

마지막으로, 부모의 양육행동과 아동의 또래 놀이 행동 간 의 상관을 살펴보면, 아동 4 세 때 아버지의 온정적 양육이 높 을수록, 아동 6 세 때 아동의 놀이 방해, 놀이 단절 점수가 낮았 고, 아동 4세 때 어머니의 통제적 양육이 높을수록, 아동 6세 때 아동의 놀이 단절 점수가 낮았다.

Table 2 는 아동의 문제 행동 모델 변인들의 평균과 변인들 간 의 상관을 보여준다. 우선, 아동 문제 행동의 모든 하위 변인들 은 서로 간에 유의미한 정적 상관 보였다. 두 번째로, 부모의 양 육행동과 아동의 문제 행동 간의 상관을 살펴보면, 아동 4 세 때 아버지의 온정적 양육과 어머니의 온정적 양육이 높을수록, 아 동 6세 때의 모든 문제 행동 하위 변인의 점수들이 낮았다. 아동 4 세 때 아버지의 통제적 양육은 위축을 제외한 6 세 때의 모든 문제 행동 하위 변인들과 상관을 보이지 않았고, 아동 4 세 때 어 머니의 통제적 양육은 6세 때의 모든 문제 행동 하위 변인들과 상관을 보이지 않았다. 마지막으로, 부모가 지각한 결혼만족도

Table 1

Means, Standard Deviations, and Intercorrelations for Study Variables of the Peer-Play Behavior Model

\begin{tabular}{|c|c|c|c|c|c|c|c|c|c|}
\hline & 1 & 2 & 3 & 4 & 5 & 6 & 7 & 8 & 9 \\
\hline \multicolumn{10}{|l|}{ Age 2} \\
\hline 1. F. Marital satisfaction & - & & & & & & & & \\
\hline \multicolumn{10}{|l|}{ Age 4} \\
\hline 3. F. Warmth-parenting & $.20^{* *}$ & $.27^{* *}$ & - & & & & & & \\
\hline 6. M. Control-parenting & .03 & .04 & $.06^{*}$ & $.27^{* *}$ & $.13^{* *}$ & - & & & \\
\hline \multicolumn{10}{|l|}{ Age 6} \\
\hline 7. Play interaction & -.02 & .06 & .06 & -.02 & .03 & .02 & - & & \\
\hline 8. Play disruption & -.02 & -.04 & $-.06^{*}$ & .02 & -.03 & .02 & $-.34^{* *}$ & - & \\
\hline
\end{tabular}

Note. $N=1094-1681$.

F. $=$ Fathers'; M. = Mothers'

${ }^{*} p<.05 .{ }^{* *} p<.01$. 
Table 2

Means, Standard Deviations, and Intercorrelations for Study Variables of the Problem Behavior Model

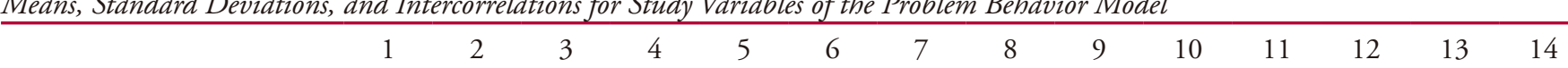

Age 2

1. F. Marital satisfaction

2. M. Marital satisfaction $.37^{* *}$

Age 4

3. F. Warmth-parenting

$$
.20^{* *} .27^{* *}-
$$

4. F. Control-parenting $\quad .03 \quad .00 \quad .17^{* *} \quad-$

5. M. Warmth-parenting $\quad .17^{* *} \quad .21^{* *} \quad .31^{* *} \quad .06^{*}-$

$\begin{array}{llllll}\text { 6. M. Control-parenting } & .03 & .04 & .06^{*} & .27^{* *} & .13^{* *}\end{array}$

Age 6

\begin{tabular}{lcccccccccccccccc} 
7. Emotionally reactive & $-.05^{*}$ & $-.08^{* *}$ & $-.09^{* *}$ & -.04 & $-.18^{* *}$ & .03 & - & & & & & \\
8. Anxious/Depressed & $-.05^{*}$ & $-.05^{*}$ & $-.09^{* *}$ & -.01 & $-.15^{* *}$ & .04 & $.72^{* *}$ & - & & & & \\
9. Somatic complaints & $-.06^{*}$ & $-.08^{* *}$ & $-.07^{* *}$ & .02 & $-.12^{* *}$ & .04 & $.47^{* *}$ & $.48^{* *}$ & - & & & \\
10. Withdrawn & -.05 & $-.08^{* *}$ & $-.10^{* *}$ & $-.05^{*}$ & $-.16^{* *}$ & -.03 & $.55^{* *}$ & $.58^{* *}$ & $.38^{* *}$ & - & & \\
11. Sleep problems & .02 & -.03 & $-.09^{* *}$ & -.05 & $-.10^{* *}$ & .03 & $.46^{* *}$ & $.52^{* *}$ & $.39^{* *}$ & $.34^{* *}$ & - & & \\
12. Attention problems & $-.09^{* *}$ & $-.10^{* *}$ & $-.16^{* *}$ & -.01 & $-.21^{* *}$ & .01 & $.46^{* *}$ & $.45^{* *}$ & $.35^{* *}$ & $.47^{* *}$ & $.34^{* *}$ & - \\
13. Aggressive behaviors & $-.09^{* *}$ & $-.16^{* *}$ & $-.15^{* *}$ & .00 & $-.24^{* *}$ & .01 & $.68^{* *}$ & $.62^{* *}$ & $.43^{* *}$ & $.54^{* *}$ & $.45^{* *}$ & $.57^{* *}$ & - \\
14. Others & $-.07^{* *}$ & $-.12^{* *}$ & $-.14^{* *}$ & .01 & $-.20^{* *}$ & .01 & $.70^{* *}$ & $.73^{* *}$ & $.53^{* *}$ & $.62^{* *}$ & $.52^{* *}$ & $.62^{* *}$ & $.75^{* *}$ & - \\
\hline$M$ & 4.21 & 3.85 & 3.37 & 3.54 & 3.66 & 3.25 & 1.71 & 2.44 & 1.26 & 1.35 & 1.63 & 1.04 & 4.63 & 5.85 \\
$S D$ & .72 & .77 & .52 & .59 & .54 & .60 & 2.06 & 2.11 & 1.60 & 1.65 & 1.59 & 1.31 & 4.46 & 4.55
\end{tabular}

Note. $N=1450-1676$.

F. $=$ Fathers'; M. = Mothers'

${ }^{*} p<.05 .{ }^{* *} p<.01$.

$\begin{array}{lll}\text { Age } 2 & \text { Age } 4 & \text { Age 6 }\end{array}$

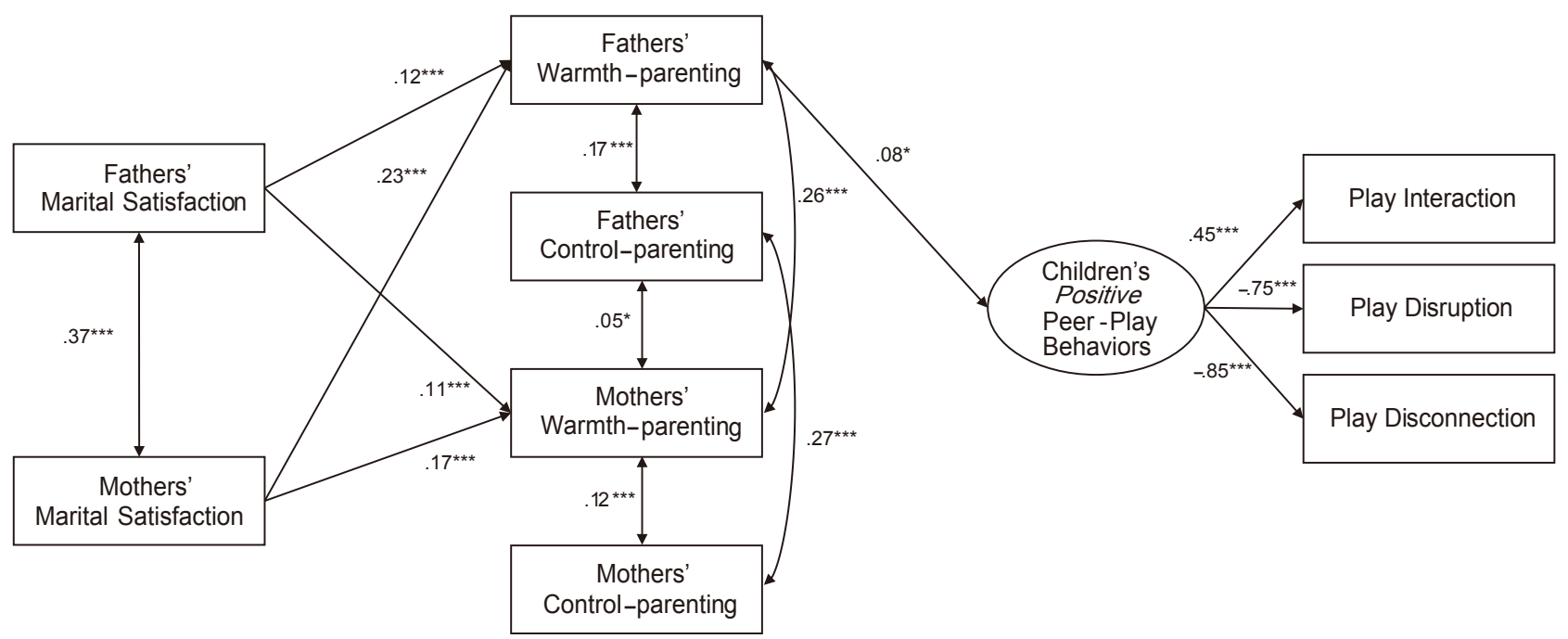

Figure 3. Child peer-play behavior model. Model fit: $\chi^{2}(12, N=1859)=21.716, p<.05$, CFI $=.993$, RMSEA = 0.021, SRMR $=$ 0.013 . Nonsignificant paths were omitted for ease of interpretation. All paths were reported in standardized path coefficients.

${ }^{*} p<.05 .{ }^{* *} p<.01 .{ }^{* * *} p<.01$. 
와 아동의 문제 행동 간의 상관을 살펴보면, 아동 2 세 때 아버지 가 지각한 결혼만족도가 높을수록, 위축과 수면문제를 제외한 6세 때의 모든 문제 행동 하위 변인의 점수가 낮았고, 아동 2세 때 어머니가 지각한 결혼만족도가 높을수록, 수면문제를 제외 한 6세의 모든 문제 행동하위 변인들의 점수가 낮았다.

\section{아동의 또래 놀이 행동 모델}

부모의 양육행동이 부모가 지각한 결혼만족도와 아동의 또래 놀이 행동을 매개하는 모델은 Figure 3에 제시되어져 있다. 우 선, 모델의 적합도는 우수하였다 $\left[\chi^{2}(12, N=1859)=21.716, p\right.$ $<.05, \mathrm{CFI}=.993, \mathrm{RMSEA}=.021, \mathrm{SRMR}=.013]$. 또한 아동의 놀이 상호작용, 놀이 방해, 놀이 단절은 아동의 또래 놀이 행 동 잠재변인을 유의미하게 설명하였다. 긍정적인 놀이 행동을 측정한 관찰변수인 놀이 상호작용은 정적인 계수(loading)를 보였고, 부정적인 놀이 행동을 측정한 관찰변수인 놀이 방해, 놀이 단절은 부적인 계수(loading)을 보였으므로, 이 관찰변인 들을 아우르는 잠재변수는 아동의 긍정적인 또래 놀이 행동 (children's positive peer play behavior)로 명명하였다.

모델에서의 유의미한 경로들을 살펴보면 다음과 같다. 첫 째, 부모가 지각한 결혼만족도와 부모의 양육행동 간의 경로 를 살펴보면, 아동이 2 세 때 아버지가 지각한 결혼만족도가 높
을수록 4 세 때 아버지의 온정적 양육 $(\beta=.12, p<.001)$ 과 어머 니의 온정적 양육 $(\beta=.11, p<.001)$ 이 증가되었다. 또한 아동 이 2 세 때 어머니가 지각한 결혼만족도가 높을수록 4 세 때 아 버지의 온정적 양육 $(\beta=.23 p<.001)$ 과 어머니의 온정적 양육 $(\beta=.17 p<.001)$ 이 증가되었다. 둘째, 부모의 양육행동과 아 동의 또래 놀이 행동 간의 경로를 살펴보면, 아동이 4세 때 아 버지의 온정적 양육이 높을수록 6세 때 아동의 긍정적인 또래 놀이 행동이 증가하였다 $(\beta=.08 p<.05)$. 마지막으로 아동이 2 세 때 부모가 지각한 결혼만족도는 6 세 때 아동의 또래 놀이 행동에 직접적 영향력을 보이지 않았다.

모델에서 보여지는 두 개의 가능한 매개경로들의 통계적 유의미성이 검증되었다. 우선, 아버지가 지각한 결혼만족도, 아버지의 온정적 양육행동, 아동의 또래 놀이 행동으로 이어 지는 매개경로는 통계적으로 유의하였다(unstandardized $\mathrm{ab}=$ $.003,95 \%$ CI $[.001, .006])$. 두 번째로, 어머니가 지각한 결혼만 족도, 아버지의 온정적 양육행동, 아동의 또래 놀이 행동으로 이어지는 매개경로도 통계적으로 유의하였다(unstandardized $\mathrm{ab}=.005,95 \%$ CI $[.001, .010])$.

\section{아동의 문제 행동 모델}

부모의 양육행동이 부모가 지각한 결혼만족도와 아동의 문

Age 2

Age 4

Age 6

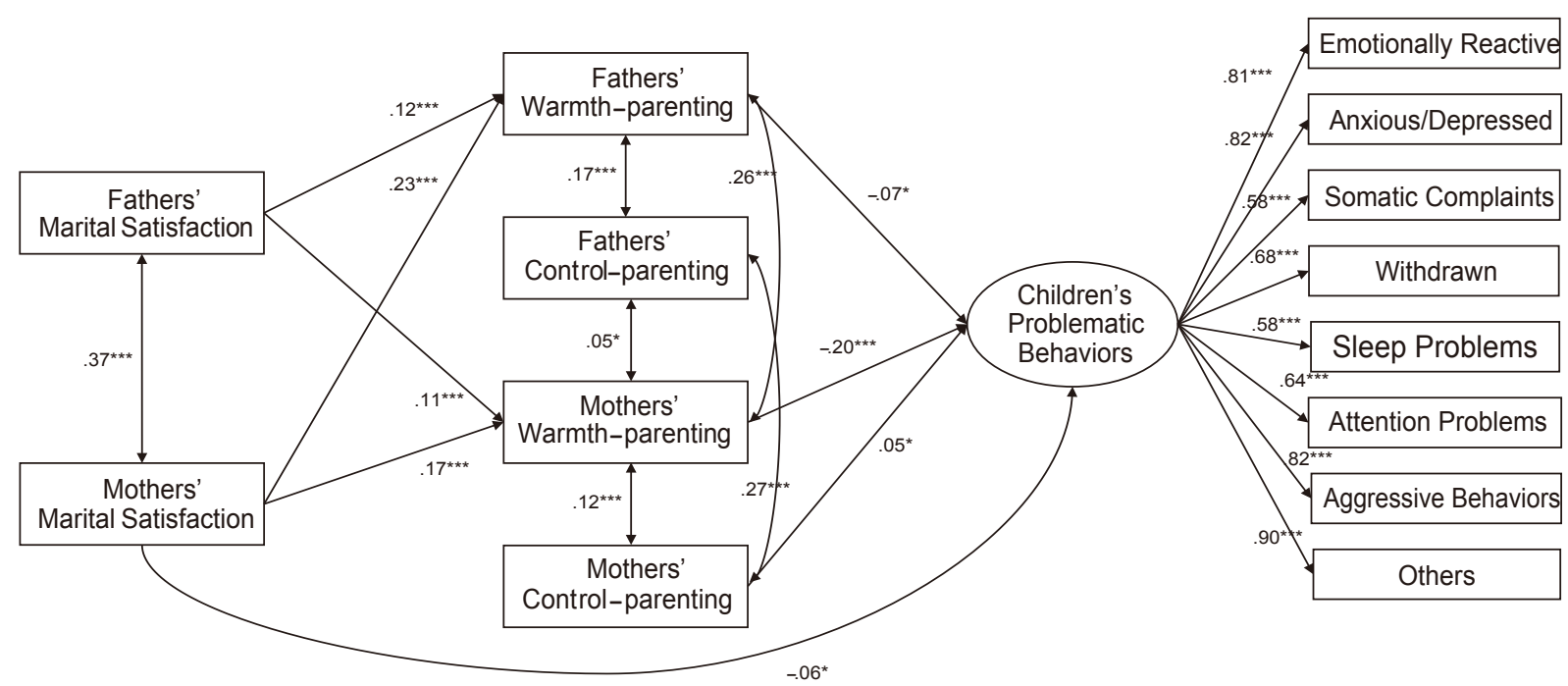

Figure 4. Child problem behavior model. Model fit: $\chi^{2}(62, N=1874)=335.521, p<.001$, CFI $=.959, \mathrm{RMSEA}=0.049$, SRMR $=0.025$. Nonsignificant paths were omitted for ease of interpretation. All paths were reported in standardized path coefficients. ${ }^{*} p<.05 .{ }^{* *} p<.01 .{ }^{* * *} p<.01$. 
제 행동을 매개하는 모델은 Figure 4에 제시되어져 있다. 우선, 모델의 적합도는 우수하였다 $\left[\chi^{2}(62, N=1874)=335.521, p<\right.$ $.001, \mathrm{CFI}=.959, \mathrm{RMSEA}=.049, \mathrm{SRMR}=.025]$. 또한 아동의 정서적 반응성, 불안/우울, 신체증상, 위축, 수면문제, 주의집 중문제, 공격문제, 기타문제는 아동의 문제 행동 잠재변인을 유의미하게 설명하였다.

모델에서의 유의미한 경로들을 살펴보면 다음과 같다. 첫 째, 부모가 지각한 결혼만족도와 부모의 양육행동 간의 경로 를 살펴보면, 모든 유의미한 경로들이 아동의 또래 놀이 행동 모델과 같았다. 둘째, 부모의 양육행동과 아동의 문제 행동 간 의 경로를 살펴보면, 아동이 4 세 때 아버지의 온정적 양육이 높을수록 6세 때 아동의 문제 행동이 감소하였다 $(\beta=-.07, p<$ .05). 또한 아동이 4 세 때 어머니의 온정적 양육이 높을수록 6 세 때 아동의 문제 행동이 감소하였고 $(\beta=-.20, p<.001)$, 아동 이 4 세 때 어머니의 통제적 양육이 높을수록 6 세 때 아동의 문 제 행동이 증가하였다 $(\beta=.05, p<.05)$. 마지막으로 부모가 지 각한 결혼만족도와 아동의 문제 행동 간의 경로를 살펴보면, 아동이 2세 때 어머니가 지각한 결혼만족도가 높을수록 6 세 때 아동의 문제 행동이 감소하였다 $(\beta=-.06, p<.05)$.

모델에서 보여지는 네 개의 가능한 매개경로들의 통계적 유의미성이 검증되었다. 첫째, 아버지가 지각한 결혼만족도, 아버지의 온정적 양육행동, 아동의 문제 행동 이어지는 매개 경로는 통계적으로 유의하였다(unstandardized ab $=-.020,95 \%$ CI [-.044, -.006]). 두 번째로, 어머니가 지각한 결혼만족도, 아 버지의 온정적 양육행동, 아동의 문제 행동으로 이어지는 매 개경로도 통계적으로 유의하였다(unstandardized $\mathrm{ab}=-.036$, 95\% CI [-.069, -.009]). 세 번째로, 아버지가 지각한 결혼만족 도, 어머니의 온정적 양육행동, 아동의 문제 행동 이어지는 매 개경로는 통계적으로 유의하였다(unstandardized $\mathrm{ab}=-.052$, $95 \%$ CI [-.087, -.026]). 마지막으로, 어머니가 지각한 결혼만 족도, 어머니의 온정적 양육행동, 아동의 문제 행동으로 이어 지는 매개경로도 통계적으로 유의하였다(unstandardized $\mathrm{ab}=$ $-.074,95 \%$ CI $[-.110,-.035])$.

\section{논의 및 결론}

본 연구는 부부의 결혼만족도가 아동의 또래 놀이 행동과 문 제행동에 미치는 영향에 있어서, 부모의 양육행동이 매개하는 지를 살펴보았다. 특히, 아버지가 지각하는 결혼만족도와 어 머니가 지각하는 결혼만족도를 분리하고, 아버지의 양육행동
과 어머니의 양육행동을 분리함으로써, 아버지와 어머니의 독 립적인 영향력을 보고자 하였다. 또한 온정적 양육행동과 통 제적 양육행동을 분리함으로써 양육행동의 차원에 따라 다른 메커니즘을 살펴보았다. 마지막으로 종단적 데이터를 이용함 으로써, 독립변인에서 시작하여, 매개변인, 종속변인으로 이 어지는 인과관계를 보다 확고히 검증하고자 하였다. 본 연구 가 보여준 결과를 논의해보면 다음과 같다.

우선 본 연구의 모델들은 부모의 결혼만족도가 부모의 온 정적 양육 행동에 영향을 준다는 것을 보여주었다. 특히, 본 연 구의 결과는 부부관계가 부모의 양육행동에 영향을 주는 메커 니즘을 설명하는 여러 이론 중, 전이가설(spillover hypothesis) 을 지지한다. 즉, 결혼에 대한 만족도가 높을수록 그로 인한 긍 정적인 정서, 감정, 분위기가 아동을 대하는 온정적인 양육 행 동을 증가시키는 방향으로 전이가 된다는 것이다. 이는 반대 로도 해석되어질 수 있는데, 결혼에 대한 만족도가 낮을수록 그로 인해 생기는 부정적인 정서, 감정, 분위기가 아동을 대하 는 온정적인 양육행동을 낮추는 방향으로 전이가 된다는 것 으로 해석되어질 수도 있다. 가족 내의 구성원들 간에 일어나 는 상호작용과 그에 따라 야기되는 정서, 감정, 분위기가 다른 구성원들 간의 관계에도 역동적으로 영향을 주고 영향을 받는 다는 것을 보여준다. 이러한 결과는 결혼만족도의 긍정적, 부 정적 감정들이 부모의 양육행동으로 전이된다는 선행연구들 의 결과(Stevenson et al., 2014; Woo, 2016)들과도 일치한다. 또 한 본 연구에서 사용된 양육행동은 결혼만족도 측정 2년 후 측 정된 변인이었음을 고려할 때, 이는 양육행동에 대한 결혼만 족도의 장기적 영향력을 보여주는 결과라고 해석되어진다. 이 러한 장기적 연관성을 설명할 수 있는 한 가지 가능성으로, 양 육행동 자체도 반복적인 학습에 의해 내재화되는 행동임을 고 려할 때, 아동이 어렸을 때 부부관계에 영향을 받아 형성되어 지는 부모의 초기 양육행동이 반복되어지며 내재화되는 것을 나타내는 것일 수 있다. 이러한 메커니즘은 향후 연구들에서 보다 명확히 검증되어질 필요가 있겠다.

부모의 양육행동에 대한 부부의 결혼만족도의 영향력에 있 어서 주목할 만한 사항으로 다음과 같은 것들이 있다. 첫째, 본 인의 결혼만족도 뿐 아니라, 상대방의 결혼만족도에 의해서도 본인의 온정적 양육행동이 영향을 받았다는 것이다. 아버지의 온정적 양육행동은, 본인의 결혼 만족도 뿐 아니라 아내의 결 혼 만족도에도 영향을 받았으며, 어머니의 온정적 양육행동은, 본인의 결혼만족도 뿐 아니라 남편의 결혼만족도에도 영향을 받았다. 아버지, 어머니 모두 상대방이 느끼는 결혼만족도에도 민감하게 영향을 받고 있다는 것을 보여주는 결과이다. 
둘째, 양육행동의 차원 중, 온정적 양육행동만이 결혼만족 도에 영향을 받았을 뿐, 통제적 양육행동은 결혼 만족도에 영 향을 받지 않았다. 부모의 결혼만족도가 높으면, 아이와 친밀 한 시간을 보내거나 아이의 의견을 존중하고 그것을 표현할 수 있게 하는 것과 같은 온정적 양육행동의 정도가 증가하는 반면, 규칙을 세워 지키게 하거나, 가정교육을 위해 아이의 행 동을 제한하는 것과 같은 통제적 양육행동의 정도는 변화하지 않았다. 이러한 통제적 양육행동은 부모의 결혼 만족도에 의 한 부모의 감정에 흔들리기 보다는, 아동의 행동 자체에 의해 영향을 받는 것일 수 있다. 본 연구의 이러한 결과는 부모의 온 정적 양육행동과 통제적 양육행동이 서로 다른 메커니즘으로 작동하고 있다는 것을 보여준다.

셋째, 본 연구 모델들은 아버지와 어머니 모두의 양육행 동이 부부관계에 영향을 받는다는 것을 보여주었다. 이는 아 버지의 양육행동이 어머니의 양육행동보다 부부관계에 더 큰 영향을 받는다는 아버지 양육행동 취약성 가설(fathering vulnerability hypothesis)과는 일치하지 않는다. 하지만 아버지 와 어머니 모두의 양육행동 또는 아버지-아동, 어머니-아동 관 계 모두가 부부관계에 영향을 받는다는 결과를 보여준 선행 연구들이 존재한다(Blodgett Salafia, Schaefer, \& Haugen, 2014; Sturge-Apple, Davies, Cicchetti, \& Cummings, 2009). 아버지 양 육행동 취약성 가설을 좀 더 명확히 검증하기 위해서는, 아동 의 연령, 사용되어진 부부관계의 측면, 문화 차이 등 다양한 요 인들이 고려되어져야 할 것으로 생각된다.

다음으로, 부부관계에서 시작하여, 부모의 양육행동을 거 쳐, 아동의 발달까지 이어지는 매개 경로의 결과를 논의하면 다 음과 같다. 우선, 또래 놀이 행동의 경우, 아버지의 온정적 양육 만이 부부의 결혼만족도와 아동의 또래 놀이 행동을 매개하였 다. 이는 아버지가 어머니보다 더 신뢰받는 놀이 상대라는 주장 (Bowlby, 1982)과 아동의 또래 관계를 포함하는 사회성 발달에 는 아버지의 영향력이 크다(Leidy et al., 2013)는 기존의 주장들 과 일치한다. 다만, 왜 그리고 어떻게 아버지가 아동의 또래 관 계에 영향을 주는지에 관한 메커니즘에 대해서는, 더 많은 연 구들이 필요할 것으로 생각된다. 한 가지 가능한 설명으로는, 아동이 또래 관계를 형성하고 유지하기 위해 필요한 능력들 을 발달시키는데 아버지가 더 큰 영향력을 주는 것일 수 있다. Grossmann 등(2002)은 어머니는 아동이 스트레스를 받았을 때 정서적 안정감을 제공하는 반면, 아버지는 아동이 주변의 환경 과 자극들을 탐색할 때 혹은 도전적인 상황에 직면하였을 때 정 서적 안정감을 준다고 주장하였다. 따라서 6세 아동에게 있어 서는 또래 관계를 형성하고 유지하는 과정들이 주변의 환경과
자극들을 적극적으로 탐색해야 하는 도전적인 상황들이라고 가정하였을 때, 아버지의 영향력이 더 클 수 있다고 보여진다.

아동의 또래 놀이 행동 모델과는 다르게, 아동의 문제 행동 의 경우, 아버지와 어머니 모두의 온정적 양육이 부부의 결혼 만족도와 아동의 문제 행동을 매개하였다. 이러한 모델 간 다 른 결과는, 아동의 발달 영역에 따라 아버지와 어머니의 역할 이 다를 수 있다는 점을 보여준다고 할 수 있다. 흥미롭게도, 또 래 놀이 행동 모델에 따르면, 어머니의 통제적 양육행동은 아 동의 문제행동을 증가시켰다. 본 연구에서 측정한 통제적 양육 행동은, 보통 긍정적 발달 결과를 예측하는 양육행동으로, 규 칙을 세우고 아동의 행동을 모니터링하는 행동적 통제 양육이 었다는 점을 고려했을 때, 이러한 결과는 예상하지 못했던 결 과였다. 한 가지 가능한 설명으로는, 아동이 아주 어렸을 때에 는 매우 허용적이기만 했던 어머니들이 4세 전후로 규칙을 세 우고 아동의 행동을 모니터링하려는 양육행동들을 증가시킬 수 있는데, 이러한 어머니의 행동 변화들이 아동들로 하여금 급작스럽고 부정적으로 인식되어질 가능성이 있다. 좀 더 구체 적인 메커니즘은 향후 연구들에서 밝혀질 수 있길 기대한다.

부부관계가 양육행동을 거치치 않고 아동발달에 미치는 직 접적인 영향을 살펴보면, 어머니가 지각한 결혼만족도가 아동 의 문제 행동에 직접적인 영향을 미쳤다. 이는 어머니의 결혼 만족도가 온정적 양육태도를 통해 아동의 외현화 문제행동에 영향을 미칠 뿐 아니라, 직접적으로도 영향을 미친다는 결과 를 보여준 우수정(2016)의 연구와 일치한다. 이러한 직접적 경 로는 어머니가 바라보는 아동의 행동이 어머니가 지각하는 결 혼만족도에 따라 달라지는 것을 보여주는 것일 수 있다. 즉 어 머니가 결혼만족도가 낮다는 것은 어머니가 스트레스 상황에 놓여있는 것이기 때문에, 그러한 상황 속에서 아동의 행동이 문제적 행동으로 지각되어질 수 있다. 또는 양육행동 이외에 도 다른 매개변인이이 존재할 수 있는데, 우수정(2016)이 언급 하였듯이, 어머니의 결혼만족도에 따라 형성되는 가정 분위기 나, 어머니가 결혼생활 속에서 보여주는 상호관계 기술 등이 어머니의 결혼만족도와 아동의 문제행동을 매개할 수 있다.

마지막으로 본 연구의 제한점 및 향후 연구를 위한 제언을 살펴보면, 첫째 본 연구는 부부관계의 여러 측면 중 결혼만족 도에 초점을 맞추었다. 향후 연구들은 부부관계의 다른 측면 들도 함께 포함시켜 부부관계의 다면적 영향력을 살펴볼 필요 가 있겠다. 둘째, 본 연구는 학령기 이전의 아동을 대상으로 하 였다. 학령기 아동들은 부부관계에 더 민감하게 영향을 받을 수 있으므로, 아동의 연령층을 확대하면, 부모의 부부관계와 부모의 양육행동이 아동의 발달의 변화에 따라 어떻게 영향을 
미치는지에 대한 통합적 이해를 제공할 수 있을 것으로 기대 되어진다. 셋째, 본 논문은 부부의 결혼만족도와 양육행동 간 의 연관성을 설명하는 전이가설, 보상가설, 분리가설을 탐색 하였다. 본 논문에서는 3 차년도에 측정한 결혼만족도와 5 차 년도에 측정한 양육행동을 사용함으로써, 전이가설이 두 변인 간의 장기적 연관성을 설명한다는 것을 검증하였으나, 결혼만 족도와 양육행동의 단기적 연관성은 다른 메커니즘을 보일 수 있다. 따라서 부부관계가 양육행동에 즉각적으로는 어떠한 영 향을 주는지에 대한 향후 연구가 필요할 것으로 여겨진다.

\section{Conflict of Interest}

No potential conflict of interest relevant to this article was reported.

\section{References}

\section{In English}

Achenbach, T. M., \& Rescorla, L. A. (2000). Manual for ASEBA Preschool Forms \& Profiles. Burlington, VT: University of Vermont, Research Center for Children, Youth, \& Families.

Baraldi, A. N., \& Enders, C. K. (2010). An introduction to modern missing data analyses. Journal of School Psychology, 48(1), 5-37. doi:10.1016/j.jsp.2009.10.001

Baumrind D. (1971) Current patterns of parental authority. Developmental Psychology, 4(1), 1-103. doi:10.1037/ h0030372

Blodgett Salafia, E. H., Schaefer, M. K., \& Haugen, E. C. (2014). Connections between marital conflict and adolescent girls' disordered eating: Parent-adolescent relationship quality as a mediator. Journal of Child and Family Studies, 23(6), 1128-1138. doi:10.1007/s10826-013-9771-9

Bowlby, J. (1982). Attachment and loss. Vol. 1: Attachment (2nd Ed.). New York: Basic Books.

Chung, H. (2004). Application and revision of the Kansas Marital Satisfaction Scale for use of Korean couples. Psychological Reports, 95(3), 1015-1022. doi:10.2466/pr0.95.3.1015-1022

Cummings, E. M., Merrilees, C. E., \& George, M. W. (2010). Fathers, marriages and families: Revisiting and updating the framework for fathering in family context. In M. E. Lamb (Ed.), The role of the father in child development (pp. 154-176). Hoboken: John Wiley.

Fantuzzo, J., Coolahan, K., Mendez, J., McDermott. P., \& Sutton-
Smith, B. (1998). Contextually-relevant validation of peer play constructs with African American head start children : Penn interactive play scale. Early Childhood Research Quarterly, 13(3), 411-431. doi:10.1016/S0885-2006(99)80048-9

Gerard, J. M., Krishnakumar, A., \& Buehler, C. (2006). Marital conflict, parent-child relations, and youth maladjustment: A longitudinal investigation of spillover effects. Journal of Family Issues, 27(7), 951-975. doi:10.1177/0192513X05286020

Grossmann, K., Grossman, K. E., Fremmer-Bombik, E., Kindler, H., Scheuerer-Englisch, H., \& Zimmermann, P. (2002). The Uniqueness of the Child-Father Attachment Relationship: Fathers' Sensitive and Challenging Play as a Pivotal Variable in a 16-year Longitudinal Study. Social Development, 11(3), 301-337. doi:10.1111/1467-9507.00202

Healey, D. M., Flory, J. D., Miller, C. J., \& Halperin, J. M. (2011), Maternal positive parenting style is associated with better functioning in hyperactive/inattentive preschool children. Infant and Child Development, 20(2), 148-161. doi:10.1002/icd.682

Hoeve, M., Dubas, J. S., Eichelsheim, V. I., van der Laan, P. H., Smeenk, W., \& Gerris, J. R. M. (2009). The relationship between parenting and delinquency: A meta-analysis. Journal of Abnormal Child Psychology, 37(6), 749-775. doi:10.1007/s10802-009-9310-8

Kawabata, Y., Alink, L. R. A., Tseng, W.-L., van Ijzendoorn, M. H., \& Crick, N. R. (2011). Maternal and paternal parenting styles associated with relational aggression in children and adolescents: A conceptual analysis and meta-analytic review. Developmental Review, 31(4), 240-278. doi:10.1016/ j.dr.2011.08.001

Krishnakumar, A., \& Buehler, C. (2000). Interparental conflict and parenting behaviors: A meta-analytic review. Family Relations, 49(1), 25-45. doi:10.1111/j.1741-3729.2000.00025.x

Leidy, M. S., Schofield, T. J., \& Parke, R. D. (2013). Fathers' contributions to children's social development. In N. J. Cabrera \& C. S. Tamis-LeMonda (Eds.), Handbook of Father Involvement: Multidisciplinary Perspectives. New York: Routledge.

Lynn, D. B., \& Sawrey, W. L. (1959). The effects of father-absence on Norwegian boys and girls. Journal of Abnormal and Social Psychology, 59(2), 258-262. doi:10.1037/h0040784

MacKinnon, D. P. (2008). Introduction to statistical mediation analysis. Mahwah: Erlbaum.

Masud, H., Thurasamy, R. \& Ahmad, M. S. (2015) Parenting styles and academic achievement of young adolescents: A systematic literature review. Quality \& Quantity, 49(6), 2411-2433. doi:10.1007/s11135-014-0120-x

McConaughy, S. H., \& Skiba, R. J. (1993). Comorbidity of externalizing and internalizing problems. School Psychology Review, 22(3), 421-436.

McLeod, B. D., Weisz, J. R., \& Wood, J. J. (2007). Examining the 
association between parenting and childhood depression: A meta-analysis. Clinical Psychology Review, 27(8), 986-1003. doi:10.1016/j.cpr.2007.03.001

Möller, E. L., Nikolić, M., Majdandžić, M., \& Bögels, S. M. (2016). Associations between maternal and paternal parenting behaviors, anxiety and its precursors in early childhood: A meta-analysis. Clinical Psychology Review, 45, 17-33. doi:10.1016/j.cpr.2016.03.002

Muthén, L. K. \& Muthén, B. O. (1998-2012). Mplus User's Guide, Seventh Edition. Los Angeles: Muthén \& Muthén.

Pinquart, M. (2016). Association of parenting styles and dimensions with academic achievement in children and adolescents: A meta-analysis. Educational Psychology Review, 28(3), 475493. doi:10.1007/s10648-015-9338-y

Pinquart, M. (2017). Associations of parenting dimensions and styles with externalizing problems of children and adolescents: An updated meta-analysis. Developmental Psychology, 53(5), 873-932. doi:10.1037/dev0000295

Schumm, W. R., Nichols, C. W., Schectman, K. L., \& Grigsby, C. C. (1983). Characteristics of responses to the Kansas Marital Satisfaction Scale by a sample of 84 married mothers. Psychological Reports, 53(2), 567-572. doi: 10.2466/ pr0.1983.53.2.567

Sears, M. S., Repetti, R. L., Reynolds, B. M., Robles, T. F., \& Krull, J. L. (2016). Spillover in the home: The effects of family conflict on parents' behavior. Journal of Marriage and Family, 78(1), 127-141. doi:10.1111/jomf.12265

Stevenson, M. M., Fabricius, W. V., Cookston, J. T., Parke, R. D., Coltrane, S., Braver, S. L., \& Saenz, D. S. (2014). Marital problems, maternal gatekeeping attitudes, and father-child relationships in adolescence. Developmental Psychology, 50(4), 1208-1218. doi:10.1037/a0035327

Stolz, L. M. (1954). Father relations of war-born children. Stanford: Stanford University Press.

Sturge-Apple, M. L., Davies, P. T., Cicchetti, D., \& Cummings, E. M. (2009). The role of mothers' and fathers' adrenocortical reactivity in spillover between interparental conflict and parenting practices. Journal of Family Psychology, 23(2), 215-225. doi:10.1037/a001419

Sturge-Apple, M. L., Davies, P. T., \& Cummings, E. M. (2006). Impact of hostility and withdrawal in interparental conflict on parental emotional unavailability and children's adjustment difficulties. Child Development, 77(6), 16231641. doi:10.1111/j.1467-8624.2006.00963.x

Suh, G. W., Fabricius, W. V., Stevenson, M. W., Parke, R. D., Cookston, J. T., Braver, S. L., \& Saenz, D. S. (2016). Effects of the interparental relationship on adolescents' emotional security and adjustment: The important role of fathers. Developmental Psychology, 52(10), 1666-1678. doi:10.1037/ dev0000204
Willner, C. J., Gatzke-Kopp, L., \& Bray, B. C. (2016). The dynamics of internalizing and externalizing comorbidity across the early school years. Development and Psychopathology, 28(4), 1033-1052. doi:10.1017/S0954579416000687

Yamagata, S., Takahashi, Y., Ozaki, K., Fujisawa, K. K., Nonaka, K., \& Ando, J. (2013). Bidirectional influences between maternal parenting and children's peer problems: A longitudinal monozygotic twin difference study. Developmental Science, 16(2), 249-259. doi:10.1111/desc.12021

\section{In Korean}

Cho, B., Lee, J., Lee, H., \& Kwon, H. (1999). Dimensions and assessment of Korean parenting style. Family and Environment Research, 37(10), 123-133

Choi, H. Y., \& Shin, H. Y. (2008). Validation of the Penn Interactive Peer Play Scale For Korean Children. Korean Journal of Child Studies, 29(3), 303-318.

Jang, Y. A., \& Lee, Y. J. (2008). The effect of father's parenting behaviors and parenting involvement on child's self-concept and prosocial behaviors. Journal of Family Relations. 13(1), 187-206.

Korea Institute of Childcare and Education. (2011, 2013, 2015). Panel Study of Korean Children 3, 5, 7th survey. [Data file and code book]. Retrieved from http://panel.kicce.re.kr/

Lee, H. (2016). Effects of mothers' parenting and their young children's intentional self control on their young children's behavior problems. The Journal of Education Research, 1(1), 139-158

Oh, K. J., \& Kim, Y. A. (2009). Manual of CBCL 1.5-5 PreschoolCaregiver Form. Seoul: Huno Consulting.

Shin, Y. -H., Chung, H. -H., \& Choi, S. -Y.(2010). An analysis of the structural relationship among children's ADHD symptoms, mothers' stress and behavior regarding nurturing, and children's social competence and self-competence. The Korean Journal of Child Education, 19(3), 143-158

Woo, S. J. (2016). The effects of mothers' marital satisfaction and parenting behavior on preschoolers' externalizing problem behaviors. Journal of Life-span Studies, 6(2), 27-40.

\section{ORCID}

Go Woon Suh https://orcid.org/0000-0003-4778-2815

Received November 5, 2017

Revision received December 6, 2017

Accepted December 14, 2017 
